\title{
Identification of 7,8-Diacetoxy-3-Arylcoumarin Derivative as a Selective Cytotoxic and Apoptosis-inducing Agent in a Human Prostate Cancer Cell Line
}

\author{
MUSILIYU A. MUSA ${ }^{1}$, LEKAN M. LATINWO ${ }^{2}$, MOISE Y. JOSEPH ${ }^{2}$ and VEERA L. BADISA ${ }^{2}$ \\ Departments of ${ }^{1}$ Chemistry and ${ }^{2}$ Biological Sciences, Florida A\&M University, Tallahassee, FL, U.S.A.
}

\begin{abstract}
Background/Aim: Coumarins are a member of the benzopyrone family of compounds with diverse and interesting pharmacological properties. In the present study, we report the in vitro cytotoxicity evaluation of 7,8Diacetoxy-3-arylcoumarin derivatives $(5 a-h)$ in human prostate (PC-3) and breast (MDA-MB-231) cancer cell lines. Materials and Methods: The cytotoxic activity was evaluated using crystal violet dye-binding assay. Furthermore, the most active compound in vitro cytotoxic activity in human noncancerous cell line and its effect on the cell-cycle phases, apoptosis proteins expression, mitochondrial membrane potential (MMP), reactive oxygen species (ROS) production and Glutathione (GSH) level were performed. Results. Among the eight compounds that were evaluated, 7,8Diacetoxy-3-(4-methylsulfonyl phenyl)coumarin (5f) was the most active derivative with highest cytotoxic activity and selectivity against the $P C-3$ cell line vs. the non-cancerous WPE1-N22 cell line. The cytotoxic action of compound $5 f$ in $P C-3$ cells is associated with the cell-cycle arrest at $-G 0 / G 1$ phase, apoptosis, loss in mitochondrial membrane potential $(M M P)$, induced reactive oxygen species (ROS) production and depletion of Glutathione (GSH) level. Conclusion: The result indicates that the presence of p-methylsulfonylphenyl group on compound $5 f$ is critical in modulating selective cytotoxic activity and induction of apoptosis via the mitochondrial apoptotic signaling pathway that is independent of cytochrome c release.
\end{abstract}

This article is freely accessible online.

Correspondence to: Professor Musiliyu A. Musa, Department of Chemistry, College of Sciences and Technology, Florida A\&M University, 1530 S Martin Luther King Jr. Blvd., 219 Jones Hall, Tallahassee, FL 32307, U.S.A. Tel: +1 8505993509, Fax: +1 8505612388, email: musiliyu.musa@famu.edu

Key Words: 3-Arylcoumarin, anticancer, cell cycle, apoptosis, oxidative stress.
Coumarins belong to the benzo- $\alpha$-pyrone family of oxygenheterocyclic compounds and are classified as naturallyoccurring coumarins (NOCs) and synthetic coumarins (SCs) $(1,2)$. The NOCs represent one of the largest phytochemicals occurring in the fruits, seeds, roots and leaves of many plant species; functioning as growth regulators, controllers of respiration, bacteriostats, fungistats, as well as prophylactics against infection (3). They are classified as simple coumarins, furanocoumarins, pyranocoumarins and pyrone-substituted coumarins based on the chemical structure of the compounds $(3,4)$. On the other hand, SCs have been the focus of chemical modification of the coumarin skeleton, in order to synthesize novel analogs with improved therapeutic activity and reduced toxicity $(5,6)$. SCs are classified as mono-, di- and polysubstituted, and fused coumarin derivatives (7). Chemically, SCs can be synthesized by various methods including the Pechmann reaction, Knoevenagel condensation, Claisen rearrangement, Perkin, Wittig, Reformatsky, Baylis Hillman and catalytic cyclization reactions $(1,8)$.

Coumarins, whether NOCs or SCs, exhibit a diverse array of pharmacological and biochemical activities such as anticancer, anti-coagulant, anti-HIV, anti-inflammatory, antimicrobial, anthelmintic and anti-oxidant properties (9-11). The structural diversity of coumarins arising from the nature of the substituent and its pattern of substitution on the core coumarin molecule influence these biological activities ( 8 , 10, 12, 13). For example: (i) acetoxycoumarins e.g. 7,8Diacetoxy-4-methylcoumarin (DAMC, Figure 1; 1) showed anti-cancer and pro-oxidant activities in different human tumor cell lines $(14,15)$ and (ii) hydroxycoumarins e.g. 7Hydroxy-4-methylcoumarin (7-OHC, Figure 1;2) displayed important pharmacological effects such as anti-cancer, antibacterial, anti-tubercular, anti-fungal, anti-neoplastic, antiHIV, and anthelmintic activities (16-18). In addition to their biological activities, coumarins are used as additives in food and cosmetics, and as optical brightening agents $(19,20)$. These interesting biological properties of coumarins have made them attractive for synthesis and therapeutic application in the treatment of various diseases. 

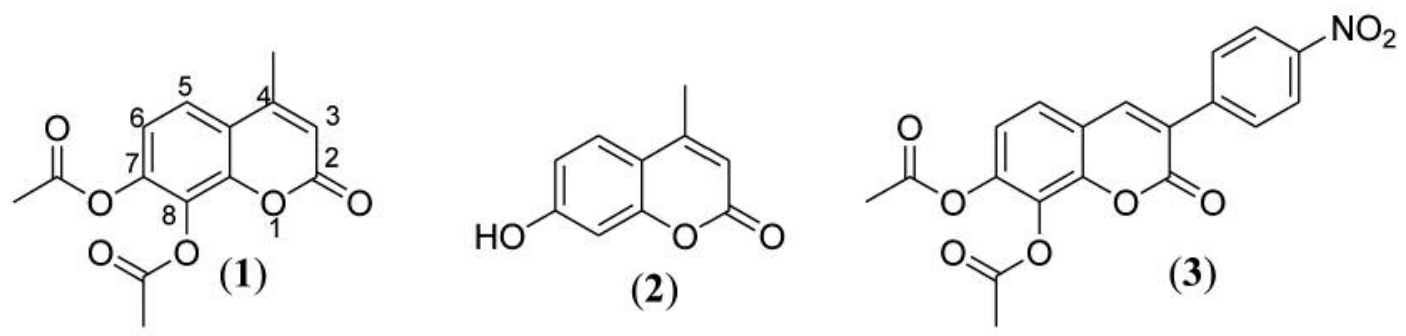

Figure 1. Structures of 7,8-Diacetoxy-4-methylcoumarin (DAMC, 1), 7-Hydroxy-4-methyl-coumarin (7-OAC, 2) and 7,8-Diacetoxy-3-(4nitrophenyl)coumarin (3).

Recent studies have shown that the incorporation of an acetoxy group on the coumarin core structure played an important role in identifying potential targets for effective new therapeutic anti-cancer drugs (21-24). Most recently, we have demonstrated that 3-arylcoumarins bearing 7,8diacetoxy group on the benzenoid ring: (i) 7,8-Diacetoxy-3(4-nitrophenyl)coumarin (Figure 1; 3) exhibited non-selective cytotoxic activity in A549, MDA-MB-231 and PC3 cancer cell lines and (ii) 7,8-Diacetoxy-3-(4-methylsulfonylphenyl) coumarin (5f; Table I) exhibited selective cytotoxic activity in A549 $(25,26)$. Previous investigations have also demonstrated that the presence of a 7,8-diacetoxy group on the coumarin molecule enhances drug activity such as anticancer, antioxidant and radicals scavenging properties (14, 15). These findings aroused our interest in the cytotoxicity studies of 7,8-Diacetoxy-3-arylcoumarins in PC-3 and MDAMB-231 cancer cell lines.

Prostate and breast cancers are the most common type of cancers among men and women, and there has been a growing research interest in the use of naturally occurring photochemicals such as coumarins to slow down the carcinogenesis process. As part of our ongoing investigation involving 7,8-Diacetoxy-3-arylcoumarins as potential anticancer agents, we herein report the in vitro cytotoxicity evaluation of 7,8-Diacetoxy-3-arylcoumarins (5a-h, Table I) in PC-3 and MDA-MB-231 cancer cell lines, and the most active compound cytotoxic activity in a non-cancerous cell line and cytotoxic mode of action in a cancer cell line.

\section{Materials and Methods}

Chemicals. Medium (F12K and RPMI1640), penicillin-streptomycin anti-biotic solution (100x), fetal bovine serum (FBS), TrypsinEDTA solution (1×), phosphate buffer (PBS), 25\% glutaraldehyde, crystal violet, IGEPAL CA-630, propidium iodide, 2',7'Dichlorofluorescin diacetate (DCFDA), Tetramethyl Rhodamine Methyl Ester (Rhodamine 123), Tamoxifen and RNase were obtained from Sigma Aldrich (St. Louis, MO, USA). KeratinocyteSFM (1X) Serum Free medium was obtained from Gibco Life Technologies (Grand Island, NY, USA). The potassium phosphates, EDTA, Triton X-100 were obtained from Thomas Scientific
Company (Swedesboro, NJ, USA). Human Apoptosis Arrays were obtained from RayBiotech, Inc. (Norcross, GA, USA). GSH-Glo ${ }^{\mathrm{TM}}$ Glutathione Assay Kit was obtained from Promega Corporation (Madison, WI, USA). Z-DEVD-fmk (caspase 3), Z-IETD-fmk (caspase 8), and Z-LEHD-fmk (caspase 9) inhibitors were obtained from MP Biomedicals, LLC (Solon, Ohio, USA). BID Antibody (Human Specific), Caspase-3 (3G2) Mouse mAb, Caspase-8 (1C12) Mouse mAb, Smac/Diablo Mouse mAb, XIAP (3B6) Rabbit mAb, Anti-rabbit IgG HRP-linked Antibody and Anti-mouse IgG HRPlinked Antibody were obtained from Cell Signaling Technology (Danvers, MA, USA). The compounds (5a-h) stock solutions were made up in DMSO and stored at $4^{\circ} \mathrm{C}$.

Cells and treatments. The human cell lines (PC-3, MDA-MB-231 and WPE1-NA22) were obtained from the American Type Culture Collection (ATCC, Rockville, MD, USA) and cultured as per the guidelines supplied. The cells were maintained in F12K (PC-3) or RPMI 1640 (MDA-MB-231) or Keratinocyte-SFM (1X) (WPE1NA22) medium containing 100 units of penicillin/ml, $100 \mu \mathrm{g}$ of streptomycin/ml, and $10 \%$ FBS (F12K and RPMI media) in T-75 $\mathrm{cm}^{2}$ flasks at $37^{\circ} \mathrm{C}$ in a $5 \% \mathrm{CO}_{2}$ incubator. The cells were plated at a density of $5 \times 10^{4}$ cells per well in a polystyrene, flat bottom $24-$ well microtiter plate (Corning Costar, Rochester, NY, USA) in complete medium and allowed to stabilize overnight in a $5 \% \mathrm{CO}_{2}$ incubator at $37^{\circ} \mathrm{C}$. Afterwards, the cells were treated with compounds $5 \mathrm{a}-\mathrm{h}$ at different concentrations $(0,10,25,50,75$ and $100 \mu \mathrm{M})$ in a final volume of $1 \mathrm{ml}$ per well in triplicate wells for each treatment for $48 \mathrm{~h}$ at $37^{\circ} \mathrm{C}$ in a $5 \% \mathrm{CO}_{2}$ incubator. The untreated cells $(0 \mu \mathrm{M})$ were taken as control cells. All studies were repeated at least two times.

Evaluation of cell viability. The cell viability was evaluated using the crystal violet dye uptake assay according to our previously reported method $(25,26)$. Glutaraldehyde $(400 \mu \mathrm{l}$ of $0.25 \%)$ was added to each well and incubated for $30 \mathrm{~min}$ at room temperature (RT). The plates were rinsed with water to wash off the dead cells and dried under airflow inside a laminar hood for 5-10 min. Crystal violet ( $400 \mu \mathrm{l}$ of $0.1 \%$ ) was added to each well, incubated for 15 min, washed and dried. Finally, $1 \mathrm{ml}$ of $0.05 \mathrm{M}$ sodium phosphate solution (monobasic) in 50\% ethyl alcohol was added to each well to solubilize the dye, and the plates were read at $540 \mathrm{~nm}$ in a plate reader (Bio-Tek EL800 Plate Reader, Winooski, VT, USA). The mean absorbance value of the control was considered as $100 \%$ and the treated sample percentages were calculated by comparing the treated samples absorbance with the mean absorbance of the control. 
Table I. The $C C_{50}$ values $(\mu M)$ for compounds 5a-h tested in PC-3 (prostate) and MDA-MB-231 (breast) cancer cell lines for a $48-h$ treatment. Data are represented as mean $\pm S D, n=3$.

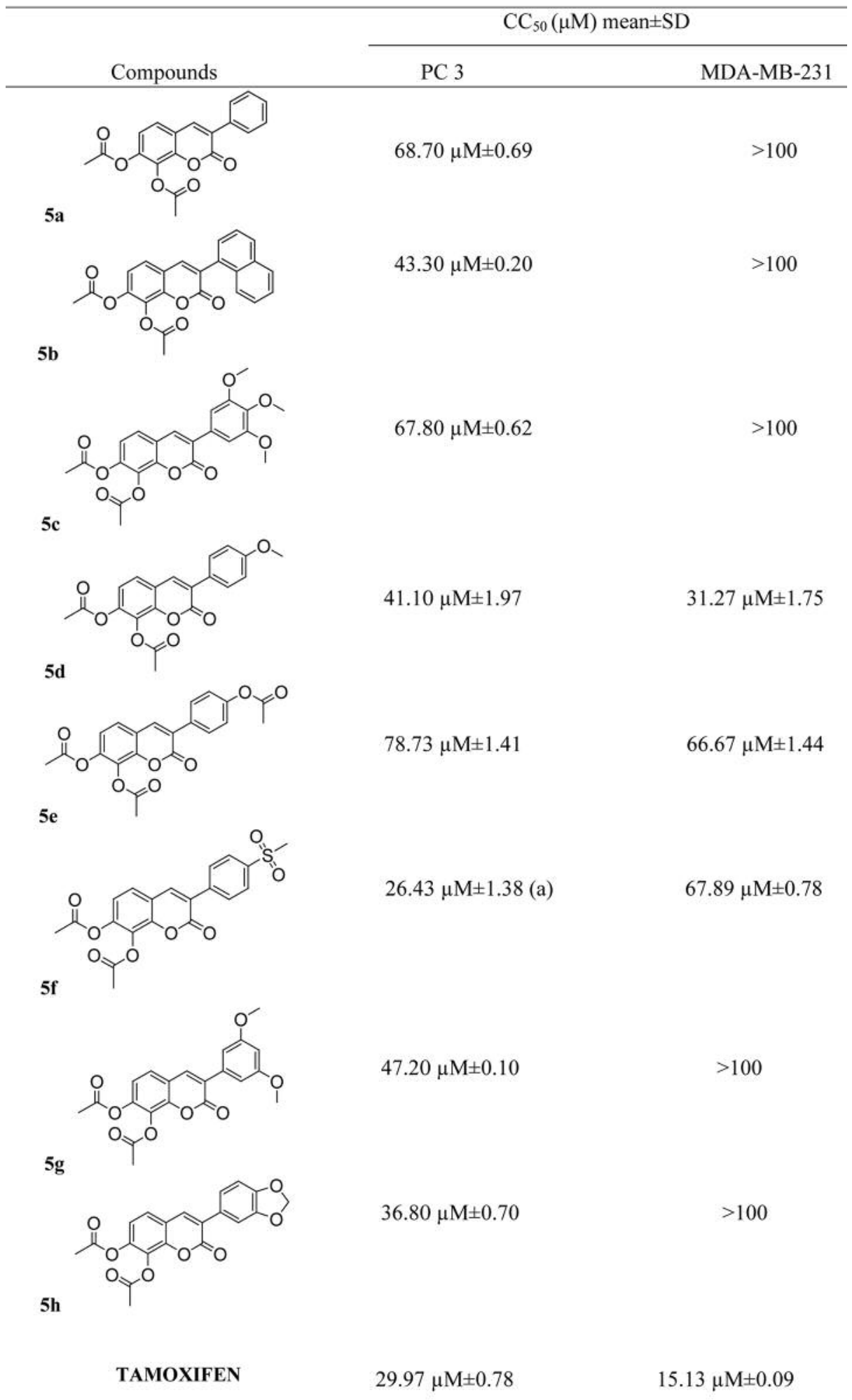

${ }^{1}$ Data represent the average of triplicate values at various concentrations; ${ }^{2}$ The cytotoxic concentration $\left(\mathrm{CC}_{50}\right)$ value was determined from the graph where the live and dead cells line graphs meet in the Graph pad Prism; ${ }^{3}$ Drug effects were determined after $48 \mathrm{~h}$ exposure; ${ }^{4}(\mathrm{a})$ : The most active compound (5f) showed no cytotoxic activity in normal prostate (WPE1-NA22) cell line (inactive; $\mathrm{CC}_{50}>100 \mu \mathrm{M}$ ). 
Cell cycle analysis. The cell cycle analysis was evaluated using C6 Accuri flow cytometer (Accuri Cytometers, Ann Arbor, MI, USA) according to our previously reported method $(25,26)$. At the end of incubation, cells were trypsinized, pelleted, washed with PBS and resuspended in $1 \mathrm{ml}$ of Vindelov's reagent (PBS $1 \times$ containing Ribonuclease A $(10 \mu \mathrm{g} / \mathrm{ml})$, Propidium Iodide $(7.5 \mu \mathrm{g} / \mathrm{ml})$ and IGEPAL CA- $630(1 \mu \mathrm{l} / \mathrm{ml})$. The cells were stained at $4{ }^{\circ} \mathrm{C}$ overnight and analyzed using a flow cytometer for the cells analysis at different phases at a low flow rate of $\sim 150$ cells/second or less.

Western blot analysis. The control and treated PC3 cell pellets were suspended in $100 \mu \mathrm{l}$ of total protein cell lysis buffer (AMRESCO, Solon, OH, USA) containing EZBlock protease inhibitor cocktail (BioVision, Milpitas, California , USA) and incubated on ice for 30 min with periodic vortexing. The tubes were centrifuged at $14,000 \mathrm{~g}$ for $20 \mathrm{~min}$ at $4^{\circ} \mathrm{C}$. The supernatant was transferred to a fresh tube and stored at $-80^{\circ} \mathrm{C}$ freezer till further use. The protein concentration of cell lysates was quantitatively measured according to the kit manual using the Pierce BCA Protein Assay kit from Life Technologies (Grand Island, NY, USA). The protein $(30 \mu \mathrm{g})$ from each sample in $1 \mathrm{X}$ SDS gel loading buffer was loaded into $15 \%$ SDS PAGE, run at $80 \mathrm{~V}$ and electrotransferred to a nitrocellulose membrane at $30 \mathrm{~V}$ for $16 \mathrm{~h}$. The nitrocellulose membrane was washed with $25 \mathrm{ml}$ of Tris buffered saline with $0.5 \%$ Tween 20 (TBS/T) buffer for $5 \mathrm{~min}$ at RT. The membrane was incubated in $10 \mathrm{ml}$ of blocking buffer for $1 \mathrm{~h}$ at RT, and incubated with a primary antibody (1:1000 dilution) in $10 \mathrm{ml}$ primary antibody dilution buffer with gentle agitation overnight at $4^{\circ} \mathrm{C}$. Later, the membrane was washed with $15 \mathrm{ml}$ of TBS/T for $5 \mathrm{~min}$ each $(3 \mathrm{X})$, incubated with the appropriate HRP-conjugated secondary antibody $(1: 2,000)$ in $10 \mathrm{ml}$ of blocking buffer with gentle agitation for $1 \mathrm{~h}$ at RT and then washed for 5 min each (3X) with $15 \mathrm{ml}$ of TBS/T. The membrane was then incubated with $10 \mathrm{ml} \mathrm{LumiGLO}{ }^{\circledR}$ (Cell Signaling Technology, Danvers, MA, USA) (0.5 ml 20X LumiGLO $^{\circledR}, 0.5 \mathrm{ml}$ 20X Peroxide and $9.0 \mathrm{ml}$ Milli-Q water) with gentle agitation for $5 \mathrm{~min}$ at RT. The excess developing solution was drained from the membrane, wrapped in plastic wrap and exposed to $\mathrm{x}$-ray film or to a ChemiDoc machine. The density of the bands on the blot was quantified using the Un-Scan-It get TM program (Silk scientific, Inc., Orem, UT, USA).

Measurement of Caspases 3, 8 and 9 activity. The involvement of Caspases 3, 8, and 9 in cytotoxic activity was determined using Caspase inhibitors. The cells were plated at a density of $5 \times 10^{4}$ cells per well in a polystyrene, flat bottom 24-well microtiter plate (Corning Costar, Rochester, NY, USA) in complete medium and allowed to stabilize overnight in a $5 \% \mathrm{CO}_{2}$ incubator at $37^{\circ} \mathrm{C}$. The cells were pre-treated with $20 \mu \mathrm{M}$ Z-DEVD-fmk (Caspase 3), ZIETD-fmk (Caspase 8), and Z-LEHD-fmk (Caspase 9) inhibitors for $1 \mathrm{~h}$ and then treated with compound $5 \mathrm{f}$ at different concentrations $(0,15$ and $30 \mu \mathrm{M})$ in a final volume of $1 \mathrm{ml}$ per well in triplicate wells for each treatment for $48 \mathrm{~h}$ at $37^{\circ} \mathrm{C}$ in a $5 \% \mathrm{CO}_{2}$ incubator. After $48 \mathrm{~h}$, the viability of cells was measured using the crystal violet dye viability assay.

Measurement of mitochondrial membrane potential (MMP). The loss of MMP was evaluated using rhodamine-123 fluorescent dye according to our previously reported method (25). The cells were plated at a density of $5 \times 10^{4}$ cells per well in a polystyrene, flat bottom 24-well microtiter plate (Corning Costar, Rochester, NY,
USA) in complete medium and allowed to stabilize overnight in a $5 \% \mathrm{CO}_{2}$ incubator at $37^{\circ} \mathrm{C}$. Afterwards, the cells were treated with different concentrations $(0,10,25,50,75$ and $100 \mu \mathrm{M})$ of compound $5 \mathrm{f}$ in a final volume of $1 \mathrm{ml}$ per well in triplicate wells for each treatment for $24 \mathrm{~h}$. At the end of the incubation, cells were fixed with $400 \mu \mathrm{l}$ of $0.25 \%$ aqueous glutaraldehyde containing $1 \mu \mathrm{M}$ rhodamine-123 for $30 \mathrm{~min}$ at RT. The cells were rinsed with tap water and dried in air-flow hood for $10 \mathrm{~min}$. The plates are then read with the excitation filter set at $485 \mathrm{~nm}$ and the emission filter at $538 \mathrm{~nm}$ in a Tecan Infinite F200 Pro plate reader (Tecan, Seestrasse, Männedorf, Switzerland).

Measurement of reactive oxygen species (ROS) production. The ROS production was evaluated using DCFDA dye according to our previously reported method (25). The cells at a concentration of 20,000 cells/ well in a final volume of $80 \mu 1$ of PBS were plated in a 96-well black plate. Then $10 \mu \mathrm{l}$ of DCFDA $(1 \mathrm{mM})$ was added to each well and incubated for $30 \mathrm{~min}$ and then treated with $0,10,25$, 50, 75, and $100 \mu \mathrm{M}$ of the compound $5 \mathrm{f}$ for $30 \mathrm{~min}$. The fluorescence was read in a Tecan Infinite F200 Pro plate reader (Tecan, Seestrasse, Männedorf, Switzerland) at an excitation wavelength of $485 \mathrm{~nm}$ and an emission wavelength of $530 \mathrm{~nm}$.

Measurement of glutathione (GSH) level. The GSH level in the PC-3 cells was quantitatively measured using GSH-Glo ${ }^{\mathrm{TM}}$ Glutathione Assay Kit (Promega, Madison, WI, USA). The experiment was performed following manual instructions. The cells at a concentration of 20,000 cells/well in a final volume of $90 \mu \mathrm{l}$ of medium were plated in a 96-well white plate. After $30 \mathrm{~min}$ incubation with compound 5f, the cells were centrifuged at $1000 \mathrm{rpm}$ for $5 \mathrm{~min}$ in a Hettich Universal $320 \mathrm{R}$ centrifuge. Then, the medium was removed and 100 $\mu \mathrm{l}$ of GSH-Glo ${ }^{\mathrm{TM}}$ reaction buffer was added and incubated for $30 \mathrm{~min}$ in an incubator. Following this step, $100 \mu$ of luciferin detection reagent was added and again incubated for $30 \mathrm{~min}$ in an incubator. The luminescence in the well of a plate was read in Tecan Infinite F200 Pro plate reader (Tecan, Seestrasse, Männedorf, Switzerland).

Statistical analysis. The data were presented as mean \pm standard deviation $(\mathrm{SD}, \mathrm{n}=3)$. All data from treated cells were presented as percentage values in comparison to the untreated control $(100 \%)$. The data were analyzed for significance by one-way ANOVA, and then compared by Dunnett's multiple comparison tests, using the GraphPad Prism Software, version 3.00 (GraphPad Software, Inc., San Diego, CA, USA). Differences with the respective untreated control were considered statistically significant when $p<0.05$. The viability and cytotoxic concentration $\left(\mathrm{CC}_{50}\right)$ graphs were plotted using the Prism 3.00 software (GraphPad Software, Inc., San Diego, $\mathrm{CA}$, USA). The $\mathrm{CC}_{50}$ (cytotoxic concentration at which $50 \%$ of the cells die) value was calculated from the graph where the live and dead cells line graphs meet using the Prism 5 Software. In the apoptosis array analysis, protein expression in cell lysate of the treated samples with $30 \%$ more or less protein expression than the control cell lysate was considered significant.

\section{Results}

Cytotoxic effect of compounds $5 a$ - $h$ in cancer cell lines. We evaluated the in vitro cytotoxic activity of 7,8-Diacetoxy-3arylcoumarins (5a-h) at different concentrations $(0,25,50$, 75 and $100 \mu \mathrm{M})$ in PC-3 and MDA-MB-231 cells after $48 \mathrm{~h}$ 
treatment using crystal violet dye binding assay. The $\mathrm{CC}_{50}$ values for compounds 5a-h are listed in Table I and indicated that compounds $5 \mathrm{a}-\mathrm{h}$ showed cytotoxic activity $\left(\mathrm{CC}_{50}=26.43 \mu \mathrm{M}\right.$ to $\left.78.73 \mu \mathrm{M}\right)$ in $\mathrm{PC}-3$ cell line, while compounds $5 \mathrm{~d}-\mathrm{f}$ showed cytotoxic activity $\left(\mathrm{CC}_{50}=31.27 \mu \mathrm{M}\right.$ to $67.89 \mu \mathrm{M})$ in $\mathrm{MDA}-\mathrm{MB}-231$ cell line with respect to untreated control cells. Overall, compound $5 \mathrm{f}\left(\mathrm{CC}_{50}=26.43 \mu \mathrm{M}\right)$ is the most active compound based on its cytotoxic activity in the PC-3 cell line. However, comparison of the cytotoxic activity of compound $5 f$ with Tamoxifen (TAM), a currently used anti-cancer drug, revealed that (i) compound $5 \mathrm{f}$ and TAM showed similar cytotoxicity in PC-3 cell line, and (ii) compound $5 \mathrm{f}$ showed twofold decrease in cytotoxicity compared to TAM in MDA-MB-231 cell line (Table I). The in vitro cytotoxicity study also revealed that compound $5 \mathrm{f}$ did not show cytotoxic activity $\left(\mathrm{CC}_{50}>100 \mu \mathrm{M}\right)$ in the noncancerous human prostate (WPE1-NA22) cell line (Table I).

Compound $5 f$ affects cell cycle. To explore the mechanisms leading to the higher cytotoxic activity of compound $5 \mathrm{f}$ (the most cytotoxic and selective compound) in PC-3 cells, we evaluated the effect of this compound on cell cycle progression for $24 \mathrm{~h}$ treatment. The control and compound $5 \mathrm{f}$ treated cells were stained with propidium iodide (PI) and the percentage of cells in the cell cycle phases were analyzed using a flow cytometer. Cell cycle analysis indicated that the percentage of PC-3 cells treated with compound $5 \mathrm{f}$ was increased significantly $(p<0.05)$ in $\mathrm{G}_{0} / \mathrm{G}_{1}$ phase at $20 \mu \mathrm{M}(4.15 \% \pm 0.01)$ and $40 \mu \mathrm{M}(15.56 \% \pm 0.02)$ in a concentration-dependent manner with respect to the untreated control cells (Figure 2).

Compound $5 f$ induces apoptosis in PC-3 cancer cells. To determine whether apoptosis contributes to compound $5 \mathrm{f}$ induced cell death in a cancer cell line, PC-3 cells were treated with $20 \mu \mathrm{M}$ of compound $5 \mathrm{f}$ for $24 \mathrm{~h}$ and protein expression associated with apoptosis was evaluated using RayBio ${ }^{\circledR}$ Human Apoptosis Antibody Array. The array analysis results indicated an up-regulation of apoptotic proteins $(30 \%$ more expression than the control untreated PC-3 cells) of which Smac/DIABLO (Second mitochondriaderived activator of caspase/direct inhibitor of apoptosisbinding protein with low isoelectric point) was the most significant up-regulated protein (data not shown). Additionally, no statistically significant change in Cytochrome $c$ release was observed. The array analysis results were further validated using western blot analysis. The results showed an up-regulation of Caspases $3 / 8$, Bid and Smac/DIABLO proteins expression, and downregulation of Cytochrome $c$ and XIAP proteins expression (Figure 3). Interestingly, Bid and Smac/DIABLO proteins were the most expressed apoptotic proteins (Figure 3).

Compound $5 f$ induces apoptosis by the activation of Caspases -3 , and -8 . To further confirm the involvement of Caspase(s) in compound $5 \mathrm{f}$ induced apoptosis, PC-3 cells were pretreated with Caspase 3 inhibitor (Z-DEVD-fmk), Caspase 8 inhibitor (Z-IETD-fmk), and Caspase-9 inhibitor (Z-LEHD-fmk) for 1 $\mathrm{h}$, followed by compound $5 \mathrm{f}$ for $48 \mathrm{~h}$ treatment. In this investigation, it was observed that the cells viability increased with Caspases $3(12.48 \% \pm 1.032)$ and $8(18.35 \% \pm 1.164)$ inhibitors pretreatment, while the cells viability did not increase with Caspase 9 inhibitor pretreatment (Figure 4).

Compound $5 f$ decreases mitochondrial membrane potential $(M M P)$. To evaluate whether compound $5 \mathrm{f}$ induced apoptotic cell death by affecting mitochondria function, PC-3 cells were treated with the compound $5 \mathrm{f}$ for $24 \mathrm{~h}$, and then stained with Rhodamine-123 dye. In this investigation, it was observed that the percentage of MMP decreased at $10 \mu \mathrm{M}$ $(5.55 \% \pm 3.002), \quad 25 \mu \mathrm{M} \quad(39.94 \% \pm 3.244), \quad 50 \mu \mathrm{M}$ $(58.43 \% \pm 3.221), 75 \mu \mathrm{M}(64.60 \% \pm 1.736)$, and $100 \mu \mathrm{M}$ $(62.12 \% \pm 0.600)$ respectively in compound $5 \mathrm{f}$ treated cells in comparison to the untreated control cells (Figure 5).

Compound $5 f$ induces oxidative stress (ROS production). In order to evaluate whether compound $5 \mathrm{f}$ induced ROS production as well, PC-3 cells were treated with the compound 5f for $30 \mathrm{~min}$ and intracellular ROS level was measured using ROS detecting fluorescence dye, DCFDA. In this investigation, it was observed that treatment of PC-3 cells with the compound $5 \mathrm{f}$ resulted in an increased fluorescence intensity at $10 \mu \mathrm{M}$ (48.38\% 6.952$), \quad 25 \mu \mathrm{M} \quad(230.72 \% \pm 15.118), \quad 50 \mu \mathrm{M}$ $(365.79 \% \pm 20.522), 75 \mu \mathrm{M}(397.99 \% \pm 13.641)$, and $100 \mu \mathrm{M}$ $(404.43 \% \pm 19.013)$ respectively in comparison to the untreated control cells (100\%) (Figure 6).

Compound $5 f$ depletes glutathione levels. In order to evaluate whether compound 5f induced apoptotic cell death in PC-3 cells was the result of excessive ROS production that led to induction of oxidative stress, GSH levels were measured in control and compound 5f treated PC-3 cells using GSHGlo $^{\text {TM }}$ Glutathione Assay Kit (Promega, Madison, WI, USA). The results indicated a concentration-dependent decrease in GSH level after 30 min with the compound $5 \mathrm{f}$ treatment in comparison to the control cells (100\%). Furthermore, it was observed that compound $5 \mathrm{f}$ treated PC-3 cells showed a slight increase in GSH level at $10 \mu \mathrm{M}(101.86 \% \pm 2.493)$, followed by significant GSH depletion at $25 \mu \mathrm{M}$ $(88.34 \% \pm 2.413), 50 \mu \mathrm{M}(78.19 \% \pm 0.654), 75 \mu \mathrm{M}(71.55 \%$ $\pm 3.336)$, and $100 \mu \mathrm{M}(71.28 \% \pm 1.364)$ (Figure 7).

\section{Discussion}

Coumarins have attracted considerable interest over the years due to their diverse pharmaceutical activities. As part of our ongoing investigation on coumarins, we herein report the in vitro cytotoxicity evaluation of 7,8-Diacetoxy-3-arylcoumarins 

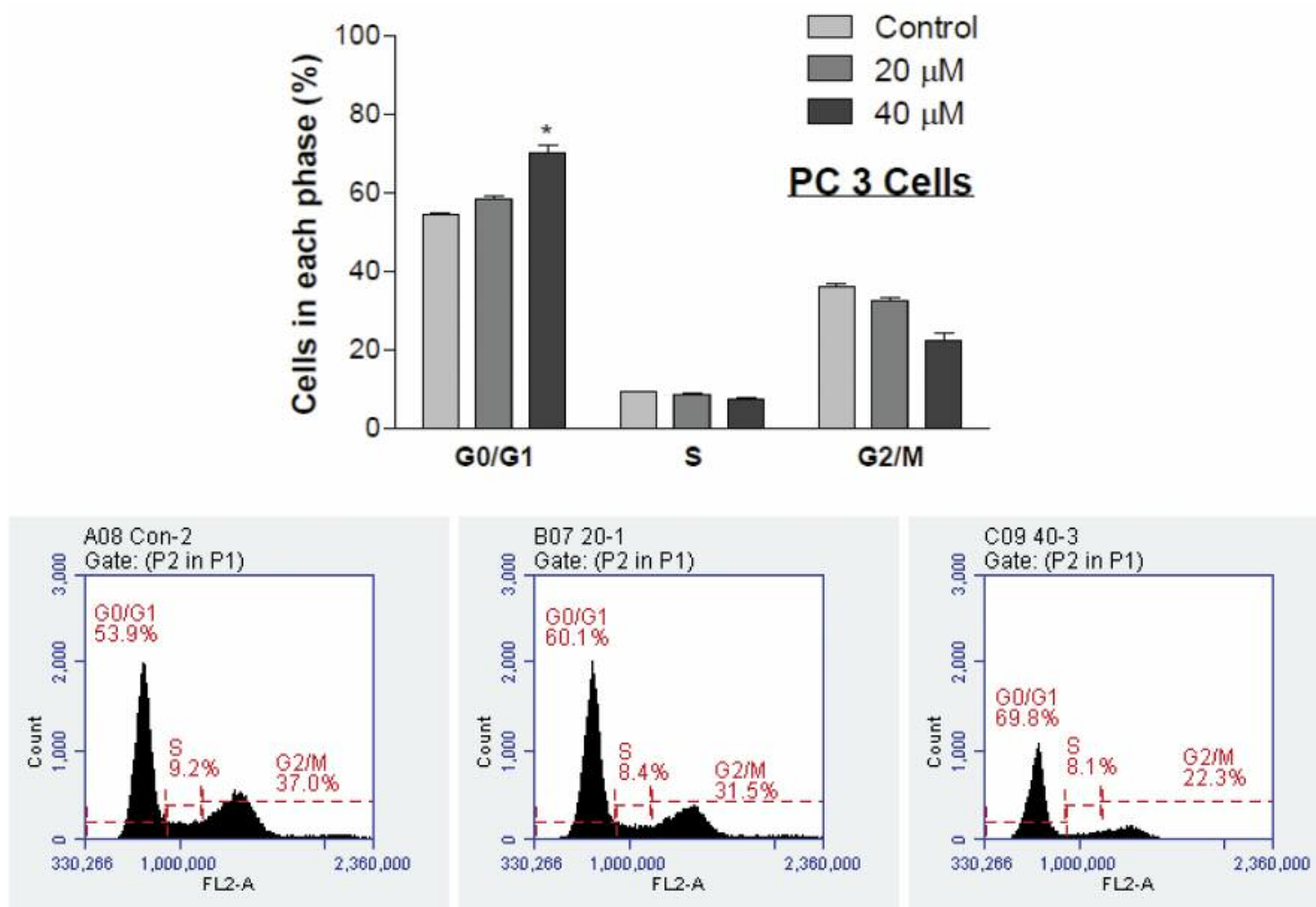

Figure 2. Effect of compound $5 f$ on cell-cycle progression in PC3 cells for 24 h treatment. Data are represented as mean $\pm S D, n=3$.

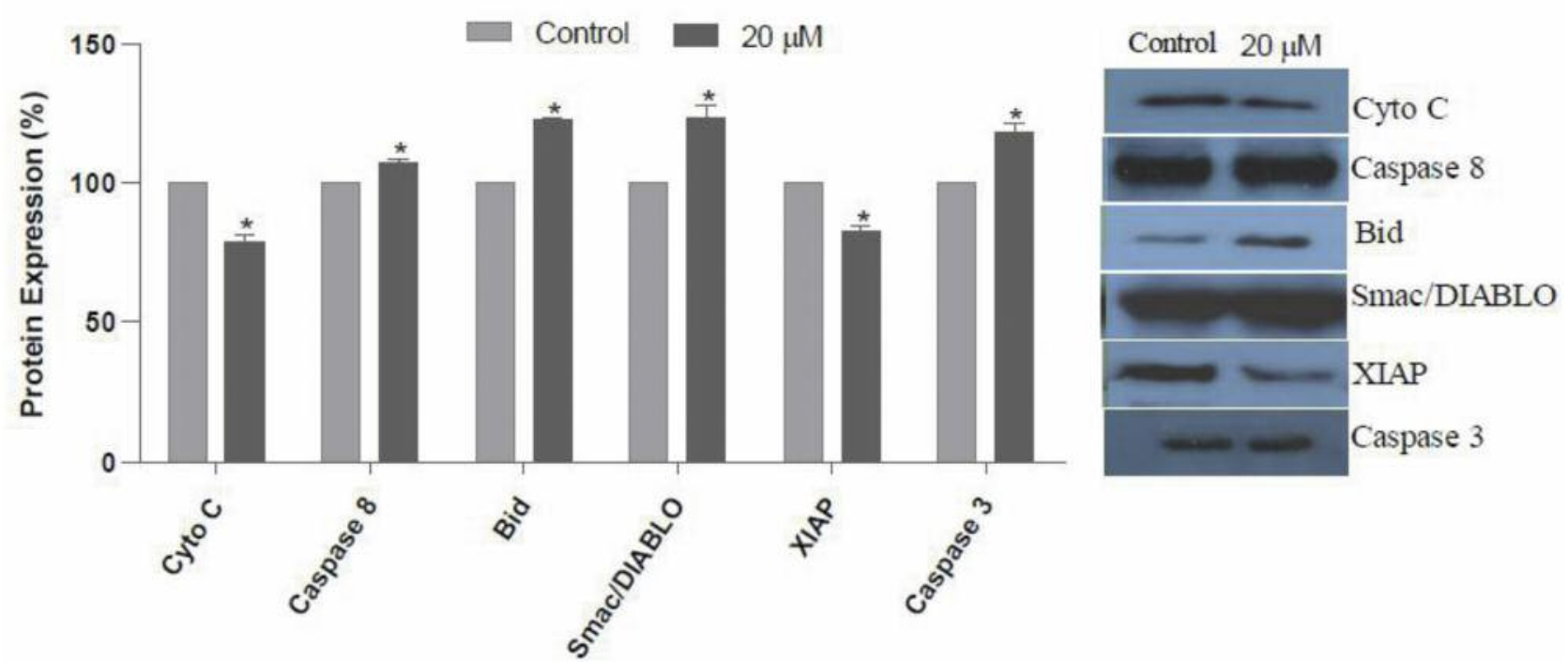

Figure 3. Effect of compound $5 f$ on Caspases 3/8, Bid, Smac/DIABLO, XIAP and Cytochrome c release proteins expression in PC3 cells after $24 \mathrm{~h}$ treatment using western blotting. Data are represented as mean $\pm S D, n=3$. 


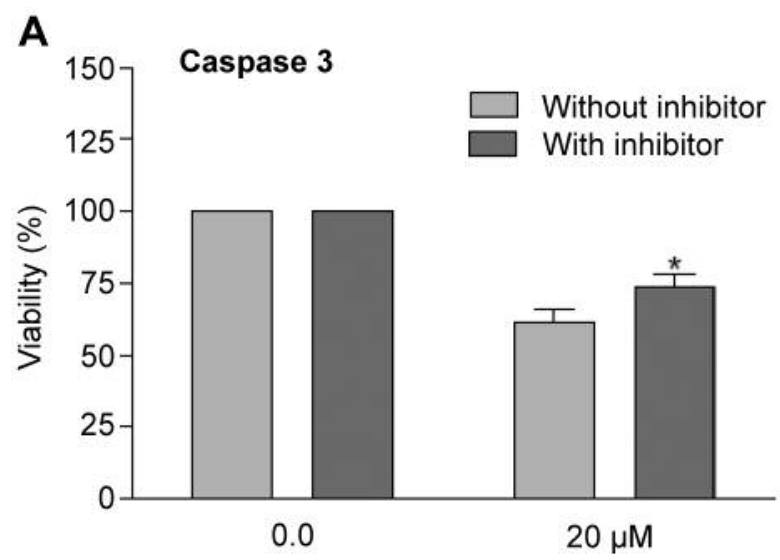

B

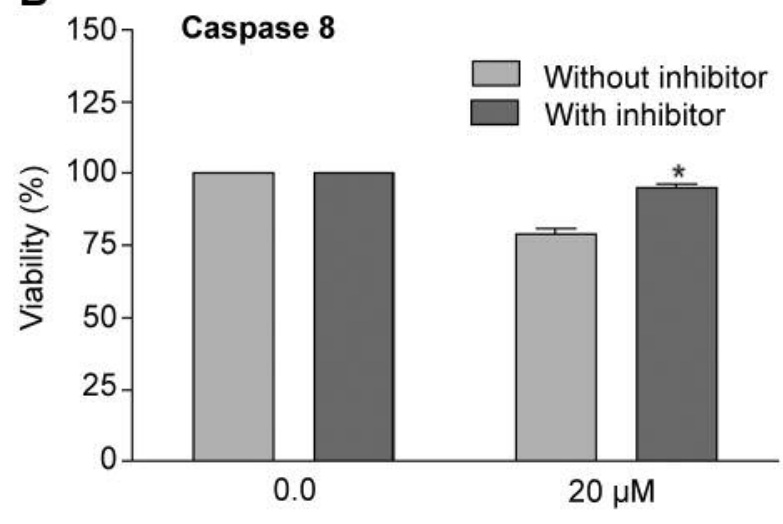

C

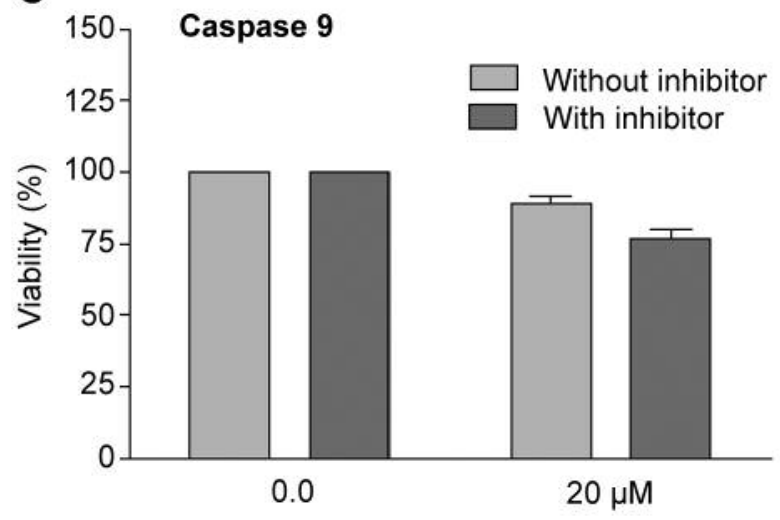

Figure 4. Effect of Caspase 3 inhibitor (Z-DEVD-fmk), Caspase 8 inhibitor (Z-IETD-fmk) and Caspase-9 inhibitor (Z-LEHD-fmk) on compound $5 f$ induced cell death of PC-3 cell for 48 h treatment. Data are represented as mean and $S D, n=3$.

(5a-h) in PC-3 and MDA-MB-231 cells. Our in vitro cytotoxicity results indicated that compound $5 \mathrm{f}$ containing $p$ (methylsulfonyl)phenyl group at the $\mathrm{C}-3$ position showed higher cytotoxic activity $(26.43 \mu \mathrm{M} \pm 1.38)$ in PC-3 cell line, while compound $5 \mathrm{~d}$ containing $p$-methoxyphenyl group at $\mathrm{C}$ -

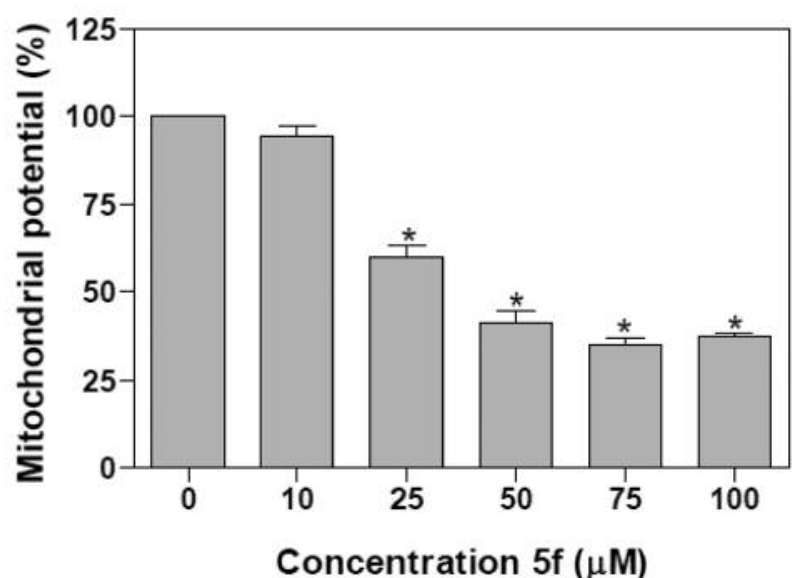

Figure 5. Effect of compound $5 f$ on mitochondrial membrane potential $(M M P)$ in PC-3 cells for $24 \mathrm{~h}$ treatment. Data are represented as mean and $S D, n=3$.

3 position showed higher cytotoxic activity $(31.27 \mu \mathrm{M} \pm 1.75)$ in MDA-MB-231 cell line (Table I). Structure-activity relationship (SAR) study clearly indicates that the observed cytotoxic activity of 7,8-Diacetoxy-3-arylcoumarins (5a-h) depends on the cell line and aryl group substituted at the C-3 position (Table I). For example, the presence of phenyl, naphthalenyl, 3, 4, 5-trimethoxyphenyl, 3, 5-dimethoxy- phenyl and benzo[d][1,3]dioxol-6-yl groups at the C-3 position did not enhance the cytotoxic activity of 7,8-Diacetoxy-3arylcoumarins (5a-c and $5 \mathrm{~g}-\mathrm{h} ; \mathrm{CC}_{50}>100 \mu \mathrm{M}$ ) in MDA-MB231 cell line. Overall, compound $5 \mathrm{f}\left(\mathrm{CC}_{50}=26.43 \mu \mathrm{M}\right)$ was the most active compound based on its cytotoxic activity in PC3 cell line and also did not show cytotoxic activity $\left(\mathrm{CC}_{50}>100 \mu \mathrm{M}\right)$ in the non-cancerous human prostate (WPE1-NA22) cell line; an indication of selective cytotoxicity. This finding supports previous report that the presence of $p$-(methylsulfonyl)phenyl groups at the C-3 position of 7,8-Diacetoxy-3-arylcoumarin ring modulates selective cytotoxic activity in certain types of cancer cell lines (26). Furthermore, comparison of the cytotoxic activity of compound $5 f$ with Tamoxifen (TAM) revealed that (i) compound 5f and TAM showed similar cytotoxicity in PC-3 cell line, and (ii) compound 5f showed twofold decrease in cytotoxicity compared to TAM in MDA-MB-231 cell line (Table I).

Cell cycle is a sequence of complex events by which cells grow and divide. Studies have demonstrated that many anticancer drugs exert their cytotoxic activity by arresting cells at various cell cycle phases $(27,28)$. In this present investigation, compound $5 \mathrm{f}$ arrested $\mathrm{PC}-3$ cells in $\mathrm{G}_{0} / \mathrm{G}_{1}$ phase in a concentration-dependent manner with respect to the untreated control cells; indicating apoptotic mode of cell death (Figure 


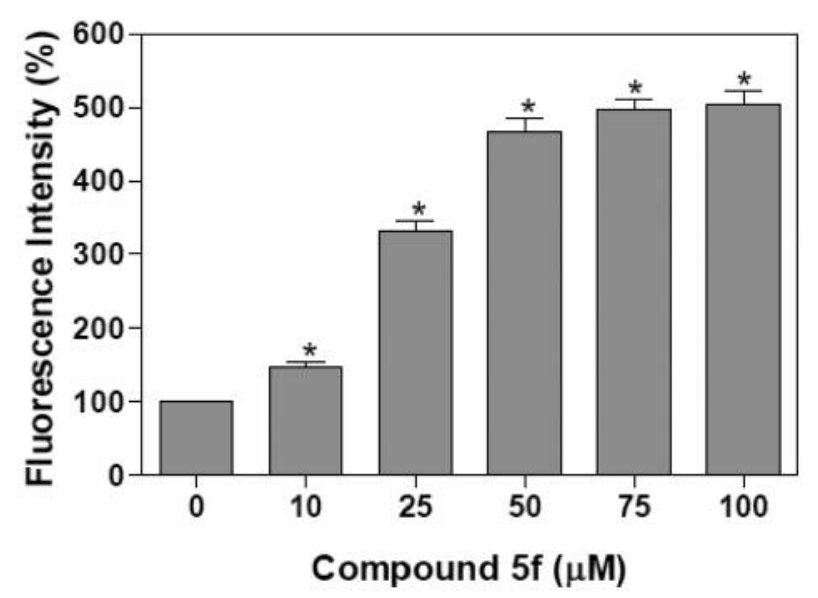

Figure 6. Effect of compound $5 f$ on reactive oxygen species (ROS) production in PC-3 cells. Data are represented as mean $\pm S D, n=3$.

2). Based on this finding, we decided to explore whether compound $5 \mathrm{f}$ induced cytotoxic activity via apoptosis. Compounds that induce apoptosis are known to kill cancer cells by stimulating apoptotic signaling either through activation of extrinsic death-receptor-mediated or intrinsic mitochondrial-mediated pathways (29). Our results from western blot analysis confirmed that compound $5 \mathrm{f}$ induced apoptosis in PC-3 cell line through the mitochondrial (intrinsic) apoptotic signaling pathway that is independent of Cytochrome $c$ release based on the up-regulation of Caspases 3/8, Bid and Smac/DIABLO proteins expression (Figure 3 ). This finding is supported by previous reports indicating that Bid serves as an initiator of Caspase 8 during Fas or TRAIL induced apoptotic signaling, leading to the generation of truncated $\mathrm{Bid}(\mathrm{tBid})$ that binds to the mitochondria and releases Smac/DIABLO from the mitochondria. Smac/DIABLO (pro-apoptogenic mitochondrial protein) interacts and neutralizes Inhibitors of apoptosis proteins (IAPs), thus allowing the activation of Caspases leading to apoptosis (30-33). It has also been reported that the interaction between Bcl 2 family members, XIAP and Smac/DIABLO, plays a major role in the intrinsic apoptotic pathway (32). Furthermore, activation of Caspase-3, -8 , and -9 are the most common processes occurring in the apoptotic signaling events $(34,35)$. The result from our Caspases measurement showed increase in the cells viability with either Caspase 3 (Z-DEVD-fmk) or Caspase 8 (Z-IETD-fmk) inhibitors pretreatment (Figure 4); indicating the involvement of Caspases $3 / 8$ in compound $5 \mathrm{f}$ induced apoptotic cell death of PC-3 cells.

Mitochondria play a key role in the activation of apoptosis and previous reports have shown that a decrease in Rhodamine-123 fluorescence is directly proportional to the loss of MMP $(36,37)$. Thus, evaluation of MMP changes using Rhodamine-123, a green-fluorescent dye, is an

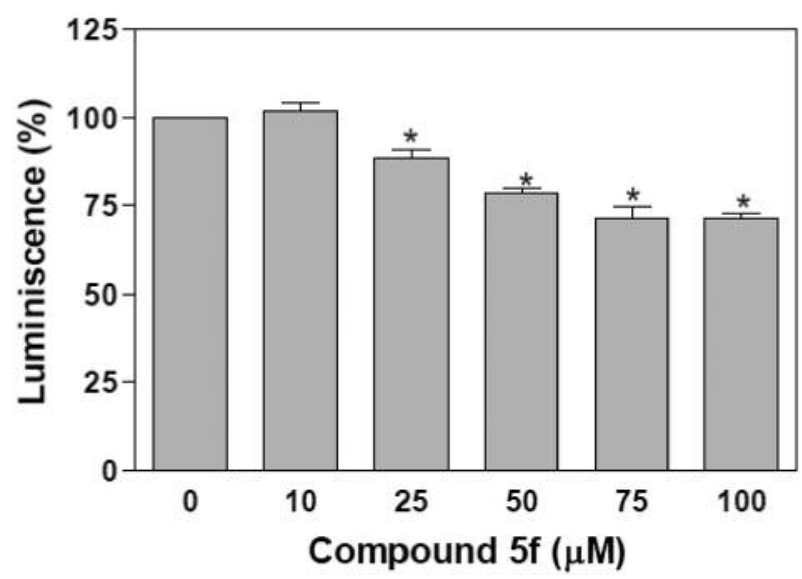

Figure 7. Effect of compound $5 f$ on GSH level in PC-3 cells. Data are represented as mean $\pm S D, n=3$.

important tool for monitoring the effect of chemicals on mitochondrial function in living cells (38). Our result from the MMP measurement showed a decrease in fluorescence intensity compared to the untreated control cells in PC-3 cells after $24 \mathrm{~h}$ treatment with Rhodamine-123 dye; indicating loss of MMP (Figure 5). This finding is consistent with previous studies suggesting that 7,8-Diacetoxy-3arylcoumarins caused loss of MMP in initiating cell death $(25,26)$. Furthermore, mitochondria are an important source of ROS production in cells and chemotherapeutic agents that raised ROS level above a safe threshold can eventually lead to cell death via apoptotic or other mechanisms $(39,40)$. The result from our intracellular ROS level measurement in PC3 cells showed concentration-dependent increase in ROS production compared to the untreated control cells $(100 \%)$ (Figure 6). This finding is consistent with previous studies suggesting that 7,8-Diacetoxy-3-arylcoumarins elevated the level of ROS production in initiating cell death $(25,26,41)$.

Glutathione (GSH, L- $\gamma$-glutamyl-cysteinyl-L-glycine) is a natural antioxidant that neutralizes harmful ROS produced in normal cells and its depletion plays a central role in cell death, including apoptotic cell death. An increase in ROS generation is known to induce oxidative stress in response to redox alteration. One way to selectively kill cancer cells without causing significant toxicity is to change the ROS levels using GSH modulation. GSH depletion causes increase susceptibility to oxidative stress and served as a potent activator of apoptosis signaling (42, 43). Our evaluation of whether compound $5 f$ induced apoptotic cell death was the result of excessive ROS production by measuring GSH levels indicates a significant GSH depletion (Figure 7). This result supports oxidative stress since GSH depletion elevates ROS level in the cells and vice versa (43). 
In conclusion, our studies demonstrated that compound $5 \mathrm{f}$ containing the $p$-methylsulfonylphenyl groups at $\mathrm{C}-3$ position exhibits highest cytotoxicity and selectivity against PC-3 cell line $v s$. the non-cancerous WPE1-N22 cell line. The cytotoxic mode of action of compound $5 \mathrm{f}$ in $\mathrm{PC}-3$ cells is associated with cell cycle arrest at $G_{0} / G_{1}$ phase, loss in mitochondrial membrane potential (MMP), induction of ROS production, depletion of GSH level and apoptosis through mitochondrial (intrinsic) apoptotic signaling pathway that is independent of Cytochrome $c$ release as a result of oxidative stress. The present investigation revealed that $p$-methylsulfonylphenyl group on the 7,8-Diacetoxy-3-arylcoumarin ring is critical in modulating selective cytotoxic activity and induction of apoptosis. The present study provided a new insight into how compound $5 \mathrm{f}$ induced cell death in PC-3 cells, that may be helpful in the development of future promising therapeutic agents for prostate cancer treatment.

\section{Conflicts of Interest}

The Authors declare that they have no financial or non-financial competing interests.

\section{Acknowledgements}

The Authors would like to dedicate this manuscript to the memory of late Mr. Moise Y. Joseph for his contribution to this work. The Authors would like to acknowledge Florida A \& M University TITLE III PROGRAM for their financial support and Mrs. Barbara Bricker, Florida A \& M University, College of Pharmacy and Pharmaceutical Sciences, Tallahassee, Florida 32307 for assistance with HPLC analysis.

\section{References}

1 Borges F, Roleira F, Milhazes N, Santana L and Uriarte E: Simple coumarins and analogues in medicinal chemistry: occurrence, synthesis and biological activity. Curr Med Chem 12: 887-916, 2005.

2 Borges F, Roleira F, Milhazes N, Uriarte E and Santana L: Simple coumarins: Privileged scaffolds in medicinal chemistry. Front Med Chem 4: 23-85, 2009.

3 Lacy A and O'Kennedy R: Studies on coumarins and coumarinrelated compounds to determine their therapeutic role in the treatment of cancer. Curr Pharm Des 10: 3797-3811, 2004.

4 Murray RDH, Mendez J and Brown SA: The Natural Coumarins: Occurrence Chemistry and Biochemistry, John Wiley (eds.), New York, USA, p. 282-289, 1982.

5 Kabeya LM, de Marchi AA, Kanashiro A, Lopes NP, da Silva CH, Pupo MT and Lucisano-Valim YM: Inhibition of horseradish peroxidase catalytic activity by new 3-phenylcoumarin derivatives: synthesis and structure-activity relationships. Bioorg Med Chem 15: 1516-1524, 2007.

6 Khoobi M, Emami S, Dehghan G, Foroumadi A, Ramazani A and Shafiee A: Synthesis and free radical scavenging activity of coumarin derivatives containing a 2-methylbenzothiazoline motif. Arch Pharm (Weinheim) 344: 588-594, 2011.
7 Kaur M, Kohli S, Sandhu S, Bansal Y and Bansal G: Coumarin: a promising scaffold for anticancer agents. Anticancer Agents Med Chem 15: 1032-1048, 2015.

8 Musa MA, Cooperwood JS and Khan MO: A review of coumarin derivatives in pharmacotherapy of breast cance. Curr Med Chem 15: 2664-2679, 2008.

9 Sandhu S, Bansal Y, Silakari O and Bansal G: Coumarin hybrids as novel therapeutic agents. Bioorg Med Chem 22: 3806-3814, 2014.

10 Bhatnagar A, Sharma PK, Kumar N and Dudhe R: A review on "Recent advances in Coumarin derivatives with their multidisciplinary actions. Der Pharmacia Lettre 2: 297-306, 2010.

11 Venugopala KN, Rashmi V and Odhav B: Review on natural coumarin lead compounds for their pharmacological activity. Biomed Res Int 2013: 1-14, 2013.

12 Kostova I, Bhatia S, Grigorov P, Balkansky S, Parmar VS, Prasad AK and Saso L: Coumarins as antioxidants. Curr Med Chem 18: 3929-395, 2011.

13 Carotti A, Carrieri A, Chimichi S, Boccalini M, Cosimelli B, Gnerre C, Carrupt PA and Testa B: Natural and synthetic geiparvarins are strong and selective MAO-B inhibitors. Bioorg Med Chem Lett 12: 3551-3555, 2002.

14 Koshy L, Dwarakanath BS, Raj HG, Chandra R and Mathew TL: Suicidal oxidative stress induced by certain antioxidants. Indian J Exp Biol 41: 1273-1278, 2003.

15 Khurana P, Kumari R, Vohra P, Kumar A, Seema, Gupta G, Raj HG, Dwarakanath BS, Parmar VS, Saluja D, Bose M, Vij A, Chaudhary NK, Adhikari JS, Tyagi YK and Kohli E: Acetoxy drug: protein transacetylase catalyzed activation of human platelet nitric oxide synthase by polyphenolic peracetates. Bioorg Med Chem 14: 575-583, 2006.

16 Bhattacharyya SS, Paul S, Mandal SK, Banerjee A, Boujedaini N and Khuda-Bukhsh AR: synthetic coumarin (4-methyl-7 hydroxy coumarin) has anti-cancer potentials against DMBA-induced skin cancer in mice. Eur J Pharmacol 614: 128-136, 2009.

17 Pankaj A, Sanjib D, Namita A, Ashish G and Baghel US: Synthesis and screening of some novel 7-hydroxy-4-methyl coumarin derivatives for antipsychotic activity. Int J Pharm Life Sci 1: 113-118, 2010.

18 Goel A, Prasad AK, Parmar VS, Ghosh B and Saini N: 7,8Dihydroxy-4-methylcoumarin induces apoptosis of human lung adenocarcinoma cells by ROS-independent mitochondrial pathway through partial inhibition of ERK/MAPK signaling. FEBS Lett 581: 2447-2454, 2007.

19 O'Kennedy R and Thornes RD: Coumarins: Biology, Applications and Mode of Action, John Wiley \& Sons (eds.), Chichester, NY, USA, 1997.

20 Bogdal DJ: Coumarins: Fast Synthesis by Knoevenagel Condensation under Microwave Irradiation. Chem Res (S): 468469, 1998.

21 Raj HG, Parmar VS, Jain SC, Goel S, Singh A, Gupta K, Rohil V, Tyagi YK, Jha HN, Olsen C E and Wengel J: Mechanism of biochemical action of substituted 4-methylbenzopyran-2-ones. Part II: Mechanism-based inhibition of rat liver microsome-mediated aflatoxin B1-DNA binding by the candidate antimutagen 7,8diacetoxy-4-methylcoumarin. Bioorg Med Chem 6: 1895-1904, 1998.

22 Raj HG, Singh BK, Kohli E, Dwarkanath BS, Jain SC, Rastogi RC, Kumar A, Adhikari JS, Watterson AC, Olsen CE and Parmar VS: Acetoxy drug: protein transacetylase: A novel enzyme mediating protein acetylation by polyphenolic peracetates. Pure Appl Chem 77: 245-250, 2005. 
23 Zarghi A, Javid FS, Ghodsi R, Dadrass OG, Daraei B and Hedayati M: Design, Synthesis and Biological Evaluation of New 5,5-Diarylhydantoin Derivatives as Selective Cyclooxygenase-2 Inhibitors. Sci Pharm 79: 449-460, 2011

24 Foote KM, Blades K, Cronin A, Fillery S, Guichard SS, Hassall L, Hickson I, Jacq X, Jewsbury PJ, McGuire TM, Nissink JW, Odedra R, Page K, Perkins P, Suleman A, Tam K, Thommes P, Broadhurs R and Wood C: Discovery of 4-\{4-[(3R)-3Methylmorpholin-4-yl]-6-[1-(methylsulfonyl)cyclopropyl] pyrimidin-2-y 1\}-1H-indole (AZ20): a potent and selective inhibitor of ATR protein kinase with monotherapy in vivo antitumor activity. J Med Chem 56: 2125-2138, 2013.

25 Musa MA, Latinwo LM, Virgile C, Badisa VL and Gbadebo AJ: Synthesis and in vitro evaluation of 3-(4-nitrophenyl)coumarin derivatives in tumor cell lines. Bioorg Chem 58: 96-103, 2015.

26 Musa MA, Joseph MY, Latinwo LM, Badisa V and Cooperwood JS: In vitro evaluation of 3-arylcoumarin derivatives in A549 cell line. Anticancer Res 35: 653-659, 2015.

27 Sa G and Das T: Anti cancer effects of curcumin: cycle of life and death. Cell Div 3: 14, 2008.

28 Mantena SK, Sharma SD and Katiyar SK: Berberine, a natural product, induces $\mathrm{G}_{1}$-phase cell cycle arrest and caspase-3dependent apoptosis in human prostate carcinoma cells. Mol Cancer Ther 5: 296-308, 2006.

29 Ghobrial IM, Witzig TE and Adjei AA: Targeting apoptosis pathways in cancer therapy. CA Cancer J Clin 55: 178-194, 2005.

30 Li S, Zhao Y, He X, Kim TH, Kuharsky DK, Rabinowich H, Chen J, Du C and Yin XM: Relief of extrinsic pathway inhibition by the Bid-dependent mitochondrial release of Smac in Fas-mediated hepatocyte apoptosis. J Biol Chem 277: 2691226920, 2002.

$31 \mathrm{Gu}$ Q, Wang JD, Xia HH, Lin MC, He H, Zou B, Tu SP, Yang Y, Liu XG, Lam SK, Wong W M, Chan AO, Yuen MF, Kung HF and Wong BC: Activation of the caspase-8/Bid and Bax pathways in aspirin-induced apoptosis in gastric cancer. Carcinogenesis 26: 541-546, 2005.

32 Kantari $\mathrm{C}$ and Walczak H: Caspase- 8 and bid: caught in the act between death receptors and mitochondria. Biochim Biophys Acta 1813: 558-563, 2011.

33 Adrain C, Creagh EM and Martin SJ: Apoptosis-associated release of Smac/DIABLO from mitochondria requires active caspases and is blocked by Bcl-2. Embo J 20: 6627-6636, 2001.
34 Parrish AB, Freel CD and Kornbluth S: Cellular mechanisms controlling caspase activation and function. Cold Spring Harb Perspect Biol 5: 1-24, 2013.

35 Kim CD, Cha JD, Li S and Cha IH: The mechanism of acacetininduced apoptosis on oral squamous cell carcinoma. Arch Oral Biol 60: 1283-1298, 2015.

36 Scaduto Jr RC and Grotyohann LW: Measurement of mitochondrial membrane potential using fluorescent rhodamine derivatives. Biophys J 76: 469-477, 1999.

37 Millot JM, Sharonov S and Manfait M: Scanning microspectrofluorometry of rhodamine 123 in multidrug-resistant cells. Cytometry 17: 50-58, 1994.

38 Jayaraman S: Flow cytometric determination of mitochondrial membrane potential changes during apoptosis of T lymphocytic and pancreatic beta cell lines: Comparison of tetramethylrhodamineethylester (TMRE), chloromethyl-X-rosamine (H2-CMXRos) and MitoTracker Red 580 (MTR580). Journal of Immunological Methods 306: 68-79, 2005.

39 Nunes C, Barbosa RM, Almeida L and Laranjinha J: Nitric oxide and DOPAC-induced cell death: from GSH depletion to mitochondrial energy crisis. Mol Cell Neurosci 48: 94-103, 2011.

40 Circu ML and Aw TY: Reactive oxygen species, cellular redox systems, and apoptosis. Free Radic Biol Med 48: 749-762, 2010.

41 Goel A, Prasad AK, Parmar VS, Ghosh B and Saini N: Apoptogenic effect of 7,8-diacetoxy-4-methylcoumarin and 7,8diacetoxy-4-methylthiocoumarin in human lung adenocarcinoma cell line: role of NF-kappaB, Akt, ROS and MAP kinase pathway. Chem Biol Interact 179: 363-74, 2009.

42 Balendiran GK, Dabur R and Fraser D: The role of glutathione in cancer. Cell Biochem Funct 22: 343-352, 2004.

43 Ortega AL, Mena S and Estrela JM: Glutathione in cancer cell death. Cancers (Basel) 3: 1285-1310, 2011. 